\title{
A Pivotal Role of Chitosan Nanoparticles in Enhancing the Essential Oil Productivity and Antioxidant Capacity in Matricaria chamomilla L.
}

\author{
Ragia Mazrou $^{1}$, Esmat F. Ali ${ }^{2}(D)$, Sabry Hassan ${ }^{2}\left(\mathbb{D}\right.$ and Fahmy A. S. Hassan ${ }^{3, *(D)}$ \\ 1 Horticulture Department, Faculty of Agriculture, Menoufia University, Shebin El Kom 32516, Egypt; \\ rogamazroua@gmail.com \\ 2 Department of Biology, College of Science, Taif University, P.O. Box 11099, Taif 21944, Saudi Arabia; \\ a.esmat@tu.edu.sa (E.F.A.); hassan@tu.edu.sa (S.H.) \\ 3 Horticulture Department, Faculty of Agriculture, Tanta University, Tanta 31527, Egypt \\ * Correspondence: fahmy_hssn@yahoo.com
}

Citation: Mazrou, R.; Ali, E.F.; Hassan, S.; Hassan, F.A.S. A Pivotal Role of Chitosan Nanoparticles in Enhancing the Essential Oil Productivity and Antioxidant Capacity in Matricaria chamomilla L. Horticulturae 2021, 7, 574. https:// doi.org/10.3390/horticulturae7120574

Academic Editor: Othmane Merah

Received: 6 November 2021

Accepted: 9 December 2021

Published: 13 December 2021

Publisher's Note: MDPI stays neutral with regard to jurisdictional claims in published maps and institutional affiliations.

Copyright: (c) 2021 by the authors. Licensee MDPI, Basel, Switzerland. This article is an open access article distributed under the terms and conditions of the Creative Commons Attribution (CC BY) license (https:// creativecommons.org/licenses/by/ $4.0 /)$.

\begin{abstract}
Chitosan is a biopolymer with several biological and agricultural applications. Recently, development of chitosan nanoparticles (CSNPs) adds additional value by further using it as an eco-friendly biostimulant. Therefore, the impact of CSNPs foliar application on the growth, essential oil productivity and antioxidant capacity of chamomile was investigated. Treatments comprised 0 , 100, 200, 300 and $400 \mathrm{mg} \mathrm{L}^{-1}$ of CSNPs applied to plants as a foliar spray. CSNPs foliar application improved the growth and productivity of chamomile plants. Relative to the control, the flower yield was increased by 52.10 and $55.74 \%$ while the essential oil percentage was increased by 57.14 and $47.06 \%$ due to CSNPs at $300 \mathrm{mg} \mathrm{L}^{-1}$ during the two seasons of study. Moreover, CSNPs enhanced the photosynthetic pigments, total soluble sugars and N, P and K percentages. Interestingly, CSNPs increased the antioxidant capacity as measured by total phenolics and the antioxidant activity (DPPH). Collectively, it is suggested that CSNPs might be a promising eco-friendly bio-stimulant and it could be an alternative strategy to improve the productivity, quality and decrease the production cost of chamomile and possibly some other medicinal species.
\end{abstract}

Keywords: antioxidant activity; biostimulants; chamomile; essential oil; phenolics; photosynthetic pigments

\section{Introduction}

Matricaria chamomilla L. (chamomile) is one of the most commonly used medicinal plants that due to its high demand is commercially cultivated in several countries worldwide [1]. It is very interesting industrial crop and its raw material is widely used in the cosmetic, pharmaceutical, perfumery and food industries due to the wide range of biologically active constituents detected in the flowers [2]. The major producers of chamomile are Argentina, Egypt, Hungary and Poland [1] and therefore it is considered one of the highest consumption widely recognized medicinal plants [3]. The essential oil of chamomile has antiseptic, carminative, sedative and anti-inflammatory effects [4].

In the last decades, a progressive reduction has been observed in the production area and therefore, increasing the productivity of medicinal plants in the area is considered a big challenge $[5,6]$. It is widely known that fertilization is the main factor affecting the productivity of chamomile. Unfortunately, the excessive application of chemical fertilizers causes serious problems, including soil fertility deterioration and higher production costs and creates pollution of the agro-ecosystem [7]. Recently, the production of chemical-free products from medicinal plants has gained more attention from researchers worldwide to guarantee their quality and safety [8]. To achieve that goal several strategies have been established such as the use of biostimulants and non-traditional fertilizers $[7,9,10]$. It has been reported that biostimulants can promote plant growth and improve the productivity 
in several species, which supports their use as plant growth enhancers [11]. Currently, the quality requirements of medicinal plants have increased and therefore chamomile production via natural methods has attracted much attention and is considered a very interesting topic [2].

Among these natural approaches, chitosan (CS) attracts massive interest as a biostimulant to improve the growth and production of horticultural crops [12]. CS (a chitin derivative) is a cationic polysaccharide, a natural antitranspirant and inexpensive compound has been used in several fields in agriculture due to its biodegradable nature and low toxicity characteristics [13]. CS application improves growth [14,15] and promotes the accumulation of secondary metabolites in several medicinal plants [14,16]. Further, it shows antioxidant activity and is able to counter oxidative damage in plant tissues $[17,18]$.

Currently, nanoparticles (NPs) are shown to affect several physiological and biochemical processes in plants and therefore they have been applied in several fields of biological research [19-23]. The physical properties of NPs are size-dependent and therefore the atom number found at the surface of NPs are more highly significant than those of bulk ones [22]. The effectiveness of chitosan nanoparticles (CSNPs) is higher than that of bulk chitosan due to its wide surface area and small size [24]. CSNPs improve the uptake of water and essential nutrients through increasing the root growth [18,22]. Despite the few abovementioned studies about using bulk chitosan to enhance plant growth, reports concerning the application of CSNPs to enhance growth and secondary metabolites in medicinal plants are scarce. To our knowledge, the impact of CSNPs on chamomile productivity has not been investigated yet. Therefore, this investigation aimed to bridge this knowledge gap.

\section{Materials and Methods}

\subsection{Plant Materials}

This study was carried out at the Faculty of Agriculture (Menoufia University, Shebin Elkom, Egypt; $30^{\circ} 33^{\prime} 24.8^{\prime \prime} \mathrm{N} 31^{\circ} 00^{\prime} 51.3^{\prime \prime}$ E) during the 2018/2019 and 2019/2020 growing seasons. Chamomile seeds were provided by the Medicinal and Aromatic Plants Department, Horticulture Research Institute, Ministry of Agriculture (Giza, Egypt). Seeds were sown on September 10th in the nursery in both seasons and the experimental soil was prepared and divided to $1.5 \times 1.8 \mathrm{~m}$ plots that contained three rows with three plants each (13,000 plants / fed). At 45 days from sowing, the seedlings were transplanted to the plots. A constant dose of $75 \mathrm{~kg} /$ fed (ammonium nitrate, $33.5 \% \mathrm{~N}$ ), $100 \mathrm{~kg} /$ fed (calcium super phosphate, $15.5 \% \mathrm{P}_{2} \mathrm{O}_{5}$ ) and $50 \mathrm{~kg} / \mathrm{fed}$ (potassium sulphate, $48 \% \mathrm{~K}_{2} \mathrm{O}$ ) as basal dressing. The soil was clay and its physical properties were ( $14.23 \%$ sand, 38.25 silt, 47.52 clay). The chemical properties of the soil were $\left(\mathrm{pH}, 8.06, \mathrm{OM}, 0.16 \%, \mathrm{EC}, 1.31 \mathrm{ds} \mathrm{m}^{-1}, \mathrm{Ca}^{+2}\right.$, 42.17 (meq $\mathrm{L}^{-1}$ ), total $\mathrm{N}^{+}, \mathrm{PO}_{4}{ }^{-3}, \mathrm{~K}^{+}$were $0.19,0.031$ and $0.041 \%$, respectively).

\subsection{CSNPs Preparation and Application}

The preparation of CSNPs was done based on the gelation of chitosan at medium molecular weight ( $80 \%$ deacetylation, Sigma AldrichSt. Louis, USA) by tripolyphosphate (TPP) anions as described by Fan et al. [25]. Briefly, a chitosan sample (1 g) was dissolved in acetic acid $(100 \mathrm{~mL})$ to prepare a $10 \mathrm{~g} \mathrm{~L}^{-1}$ solution. The solution was stirred for $30 \mathrm{~min}$ at $60{ }^{\circ} \mathrm{C}$ and after that the stirring was continued at lab temperature. Then, adjusting the $\mathrm{pH}$ of solution to 4.8 was done using $1.0 \mathrm{M} \mathrm{NaOH}$. The Tween-20 surfactant $(400 \mathrm{~mL})$ was added to the chitosan solution and then centrifuged for $10 \mathrm{~min}$ at $10,000 \times \mathrm{g}$. The aqueous solution of Na-TPP was gradually added into the solution through magnetic stirring at room temperature. After that, the mixture was re-centrifuged at $10,000 \times g$ for $35 \mathrm{~min}$ for CSNPs collection. Finally, the supernatant was preserved at $4{ }^{\circ} \mathrm{C}$ until application. Before the foliar spray, four levels of CSNPs $\left(100,200,300\right.$ and $\left.400 \mathrm{mg} \mathrm{L}^{-1}\right)$ were prepared. Two weeks after transplanting, CSNPs foliar spray was applied and was repeated three times at two week intervals and control plants were sprayed with distilled water. The treatments were arranged in a complete randomized design (CRD) as reported by Snedecor and Cochran [26] and each treatment had three replicates. 


\subsection{Growth and Yield Measurements}

After the flowering period, the plant height and branch number were determined. Meanwhile, the flowers were continuously collected and air dried until the end of flowering period, then the total dry flower yield per plant was measured.

\subsection{Relative Water Content (RWC)}

At the beginning of flowering stage, the RWC was determined in chamomile herb using the methodology of Weatherley [27] by the following formula: $\left(\mathrm{W}_{\text {fresh }}-\mathrm{W}_{\text {dry }}\right) /\left(\mathrm{W}_{\text {turgid }}-\mathrm{W}_{\mathrm{dry}}\right) \times 100$, since $W_{\text {fresh }}$ is the fresh weight of sample, $W_{\text {turgid }}$ is the turgid weight of sample after saturating with distilled water at $4{ }^{\circ} \mathrm{C}$ for $24 \mathrm{~h}$, and $\mathrm{W}_{\text {dry }}$ is the oven-dry weight of the sample $\left(70{ }^{\circ} \mathrm{C}\right.$ for $\left.48 \mathrm{~h}\right)$.

\subsection{Essential Oil Determination}

The hydro-distillation method was used to extract the flower essential oil in a Clevenger apparatus for $3 \mathrm{~h}$ and the essential oil percentage was assessed as described in British Pharmacopea [28], by the following formula:

Essential oil $(\%)=$ oil volume in the graduated tube/weight of sample $\times 100$.

Triplicate samples were distilled for each treatment and the average value is considered the mean of the treatment and the essential oil yield per plant was calculated.

\subsection{Photosynthetic Pigments Assessment}

The total chlorophyll and carotenoids were extracted and investigated as described by Lichtenthaler and Wellburn [29]. Briefly, herb tissue ( $0.2 \mathrm{~g})$ was ground using a mortar in the presence of liquid $\mathrm{N}_{2}$ to obtain a powder. Then, this leaf powder was extracted by acetone $(80 \%)$. After that, the sample was centrifuged for $15 \mathrm{~min}$ at $12,000 \times g$. The absorbance of the supernatant was investigated at 662,645 and $470 \mathrm{~nm}$. The calculation of the photostynthetic pigments was performed by the following equations:

$$
\begin{gathered}
\text { Chl a }=11.75 . A_{662}-2.35 . A_{645} \\
\text { Chl b }=18.61 . A_{645}-3.96 . A_{662} \\
\text { Total Chl }=\mathrm{Chl} \mathrm{a}+\mathrm{Chl} \mathrm{b} \\
\mathrm{Car}=1000 \times A_{470}-2.27 \times \mathrm{Chl} \mathrm{a}-81.4 \times \mathrm{Chl} \mathrm{b} / 227
\end{gathered}
$$

where $A_{645}, A_{662}$ and $A_{470}$ are the absorbance at the wavelengths of 645,662 and $470 \mathrm{~nm}$, respectively.

\subsection{Total Soluble Sugars (TSS) Determination}

The TSS is assessed as mentioned by Shi et al. [30]. Briefly, a sample of herb (0.2 g) was homogenized in $96 \%$ ethanol $(5 \mathrm{~mL})$ and the centrifuged for $10 \mathrm{~min}$ at $3500 \times \mathrm{g}$. the supernatant $(1 \mathrm{~mL})$ was reacted with anthrone reagent $(3 \mathrm{~mL})$ which consists of $150 \mathrm{mg}$ anthrone $+100 \mathrm{~mL}$ concentrated $\mathrm{H}_{2} \mathrm{SO}_{4}$. After that, this mixture was incubated in boiling water bath for $10 \mathrm{~min}$. Finally; the absorbance was monitored at $630 \mathrm{~nm}$ using a spectrophotometer (LKB-Novaspec II, Pharmacia, Uppsala, Sweden) and the soluble sugar was measured using the standard of glucose. The TSS was expressed as $\mathrm{mg} \mathrm{g}^{-1} \mathrm{FW}$.

\subsection{Assessment of Total Phenol Content}

To investigate the phenolic content, the methodology reported by McDonald et al. [31] was followed. A $1 \mathrm{~g}$ powder sample was stirred in $80 \%$ methanol $(50 \mathrm{~mL})$ for $48 \mathrm{~h}$ using a blender. After that, the solvent was removed and the extract was kept at $4{ }^{\circ} \mathrm{C}$. a sample of $0.5 \mathrm{~mL}$ from diluted extract $\left(1: 10 \mathrm{~g} \mathrm{~mL}^{-1}\right)$ or gallic acid as a standard phenolic compound was mixed with Folin-Ciocalteu reagent ( $5 \mathrm{~mL}$, diluted 1:10 using distilled water) and $4 \mathrm{~mL}$ of $1 \mathrm{M}$ aqueous $\mathrm{Na}_{2} \mathrm{CO}_{3}$. The total phenolics was spectrophotometrically determined at $765 \mathrm{~nm}$ and recorded as gallic acid equivalents/g of extract $\left(\mathrm{mg} \mathrm{GAE} \mathrm{g}^{-1} \mathrm{DW}\right)$. 


\subsection{Antioxidant Activity (DPPH Assay)}

The 1,1-diphenyl-2-picrylhydrazyl (DPPH) reagent was used for free radical scavenging activity determination as described by Brand-Williams et al. [32]. The sample extract was dissolved in $85 \%$ aqueous methanol. After that, DPPH solution $(1.5 \mathrm{~mL}, 20 \mu \mathrm{g} \mathrm{mL})$ was reacted with extract $(0.5 \mathrm{~mL})$ and stirred in the dark. After five minutes of reaction, decolorization was investigated at $517 \mathrm{~nm}$ and compared with a blank. The DPPH was calculated as the inhibition percentage ( $\mathrm{I} \%)$ using the following formula:

$$
\mathrm{I}(\%)=100 \times\left(\mathrm{A}_{\text {blank }}-\mathrm{A}_{\text {sample }}\right) / \mathrm{A}_{\text {blank }}
$$

where $A_{\text {blank }}$ and $A_{\text {sample }}$ are the absorbance of control and the sample at 30 min reaction, respectively. The extract level generating $50 \%$ inhibition $\left(\mathrm{IC}_{50}\right)$ is reported as the antiradical activity.

\subsection{N, P and K Assessment}

At the end of flowering, herb samples were taken to estimate the N, P and K percentages. The samples were oven dried and then ground and digested with a mixture of $\mathrm{H}_{2} \mathrm{SO}_{4}$ and perchloric acid (5:1) as described by A.O.A.C. [33]. The micro-Kjeldahl digestion method was used for $\mathrm{N}$ determination as reported by Nelson and Sommers [34]. The P percentage was assessed colorimetrically by spectrophotometry (Pharmacia LKBNovaspec II) according to Jackson [35] while the K percentage was measured using a flame photometer [36].

\subsection{Statistical Analysis}

This experiment was set as complete randomized design (CRD). The results of each experimental season were collected and subjected to the analysis of variance (ANOVA) by the SPSS 13.3 program (IBM, New York, NY, USA). Statistical differences and means separation were assessed by LSDs test at $p \leq 0.05$ level. Principal components analysis (PCA) was performed using the Analyse-it Software (v. 5.6 for Excel, Ltd., Leeds, UK).

\section{Results}

\subsection{Growth Characters}

All levels of CSNPs significantly increased the plant height and branch number in comparison to the control in both experimental seasons. The increase in both characters was gradual with increasing the CSNPs level until $300 \mathrm{mg} \mathrm{L}^{-1}$ however the highest level of CSNPs (400 mg L ${ }^{-1}$ ) did not have any more impact than $300 \mathrm{mg} \mathrm{L}^{-1}$ (Table 1). The plant height and branch number were increased by 31.16 and $26.03 \%$ in the first season and 32.20 and $39.40 \%$ in the second one when the treatment of $300 \mathrm{mg} \mathrm{L}^{-1}$ was applied relative to the control.

Table 1. Impact of chitosan nanoparticles (CSNPs) on plant height and branch number of Matricaria chamomilla L. in the two experimental seasons. Data are means \pm SE $(n=3)$. In each column, least significant difference was calculated and letters represent statistical differences among treatments at $p \leq 0.05$.

\begin{tabular}{ccccc}
\hline \multirow{2}{*}{$\begin{array}{c}\text { CSNPs } \\
\left(\mathbf{m g ~ L}^{-1}\right)\end{array}$} & \multicolumn{2}{c}{ 2018/2019 Season } & \multicolumn{2}{c}{ 2019/2020 Season } \\
\cline { 2 - 5 } & Plant Height $\mathbf{( c m )}$ & Branch Number/Plant & Plant Height (cm) & Branch Number/Plant \\
\hline Control & $41.58 \pm 0.97 \mathrm{~d}$ & $11.33 \pm 0.55 \mathrm{c}$ & $39.85 \pm 1.04 \mathrm{~d}$ & $10.66 \pm 0.47 \mathrm{c}$ \\
100 & $44.72 \pm 0.88 \mathrm{c}$ & $11.72 \pm 0.61 \mathrm{c}$ & $42.67 \pm 0.82 \mathrm{c}$ & $11.17 \pm 0.51 \mathrm{c}$ \\
200 & $49.17 \pm 1.03 \mathrm{~b}$ & $12.89 \pm 0.49 \mathrm{~b}$ & $47.29 \pm 0.91 \mathrm{~b}$ & $12.38 \pm 0.43 \mathrm{~b}$ \\
300 & $54.54 \pm 0.92 \mathrm{a}$ & $14.28 \pm 0.64 \mathrm{a}$ & $52.68 \pm 1.06 \mathrm{a}$ & $14.86 \pm 0.61 \mathrm{a}$ \\
400 & $53.22 \pm 0.83 \mathrm{a}$ & $14.45 \pm 0.57 \mathrm{a}$ & $52.13 \pm 0.86 \mathrm{a}$ & $14.45 \pm 0.54 \mathrm{a}$ \\
LSD 0.05 & 1.79 & 0.61 & 1.67 & 0.59 \\
\hline
\end{tabular}




\subsection{Flower Yield}

The dry flower yield in response to CSNPs levels was presented in Figure 1A. The flower yield was significantly enhanced as a result of any CSNPs level compared to the control during the two seasons of study. The increase in the concentration of CSNPs, the increase in the flower yield, however there is no significant difference between 300 and $400 \mathrm{mg} \mathrm{L}^{-1}$ treatments in this respect. Chamomile plants that sprayed with $300 \mathrm{mg} \mathrm{L}^{-1}$ CSNPs increased flower yield by 52.10 and $55.74 \%$ in both seasons, respectively.
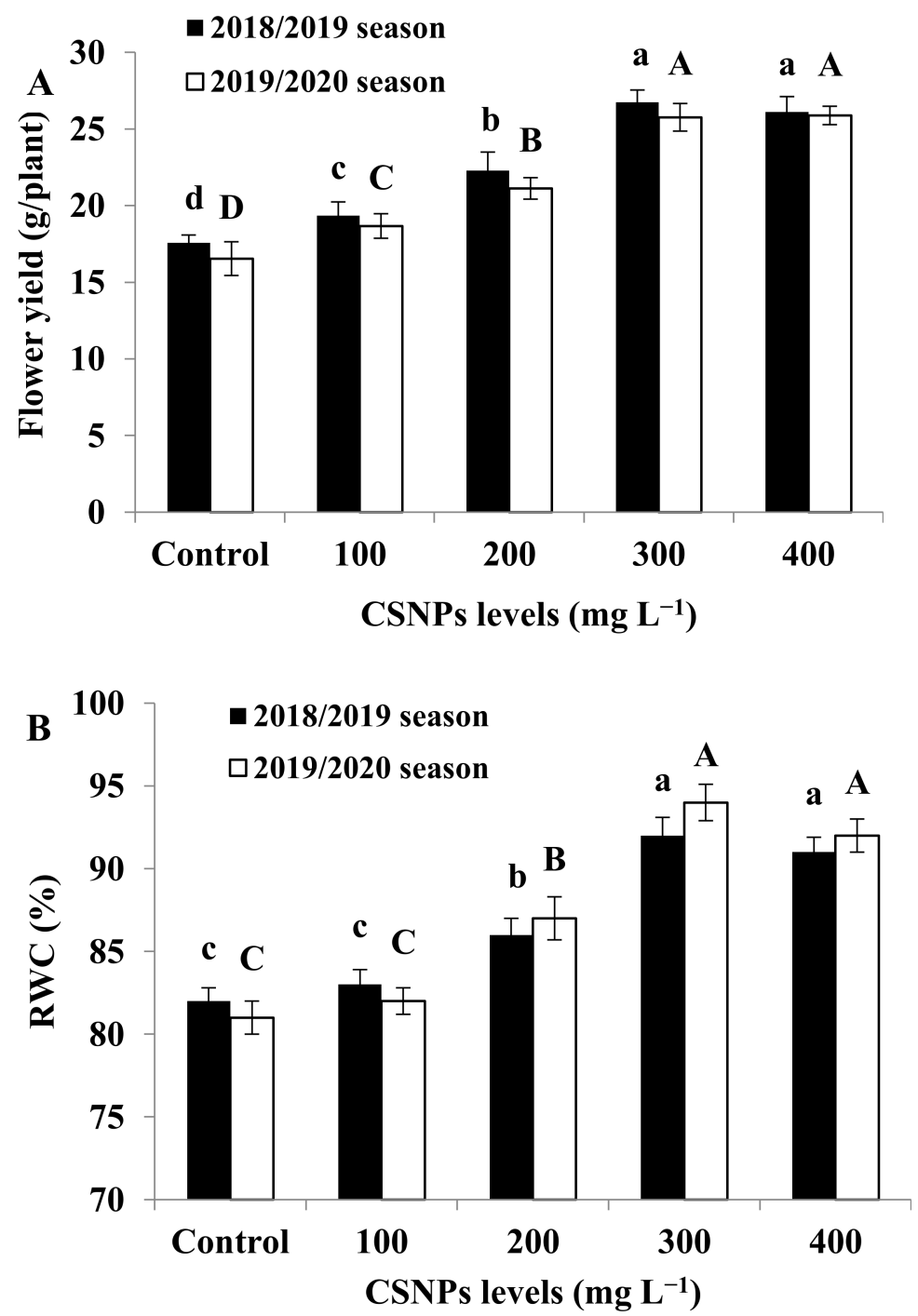

Figure 1. Impact of chitosan nanoparticles (CSNPs) on (A), dry flower yield; (B), relative water content of Matricaria chamomilla in the two experimental seasons. Data are means $\pm \mathrm{SE}(n=3)$. In each season, letters represent statistical differences among the treatments at $5 \%$ probability.

\subsection{Relative Water Content (RWC)}

Foliar spraying with CSNPs considerably improved the RWC in both seasons compared to unsprayed plants (Figure 1B). Increasing the CSNPs level gradually increased the RWC and reached its maximum value by the concentration of $300 \mathrm{mg} \mathrm{L}^{-1}$. A further increase in CSNPs dose caused a slight reduction in RWC but without significant difference with $300 \mathrm{mg} \mathrm{L}^{-1}$ level during the two seasons of study.

\subsection{Essential Oil Content}

The essential oil percentage and yield/plant were significantly enhanced due to CSNPs foliar application relative to control in 2018/2019 and 2019/2020 seasons (Figure 2). 
A gradual and significant increase in both parameters were observed when the CSNPs level was increased from 100 to $300 \mathrm{mg} \mathrm{L}^{-1}$ while no impact was obtained when plants were sprayed with $400 \mathrm{mg} \mathrm{L}^{-1}$. Relative to the control, the essential oil percentage was increased by 57.14 and $47.06 \%$ when the treatment of $300 \mathrm{mg} \mathrm{L}^{-1}$ was applied in both seasons, respectively.
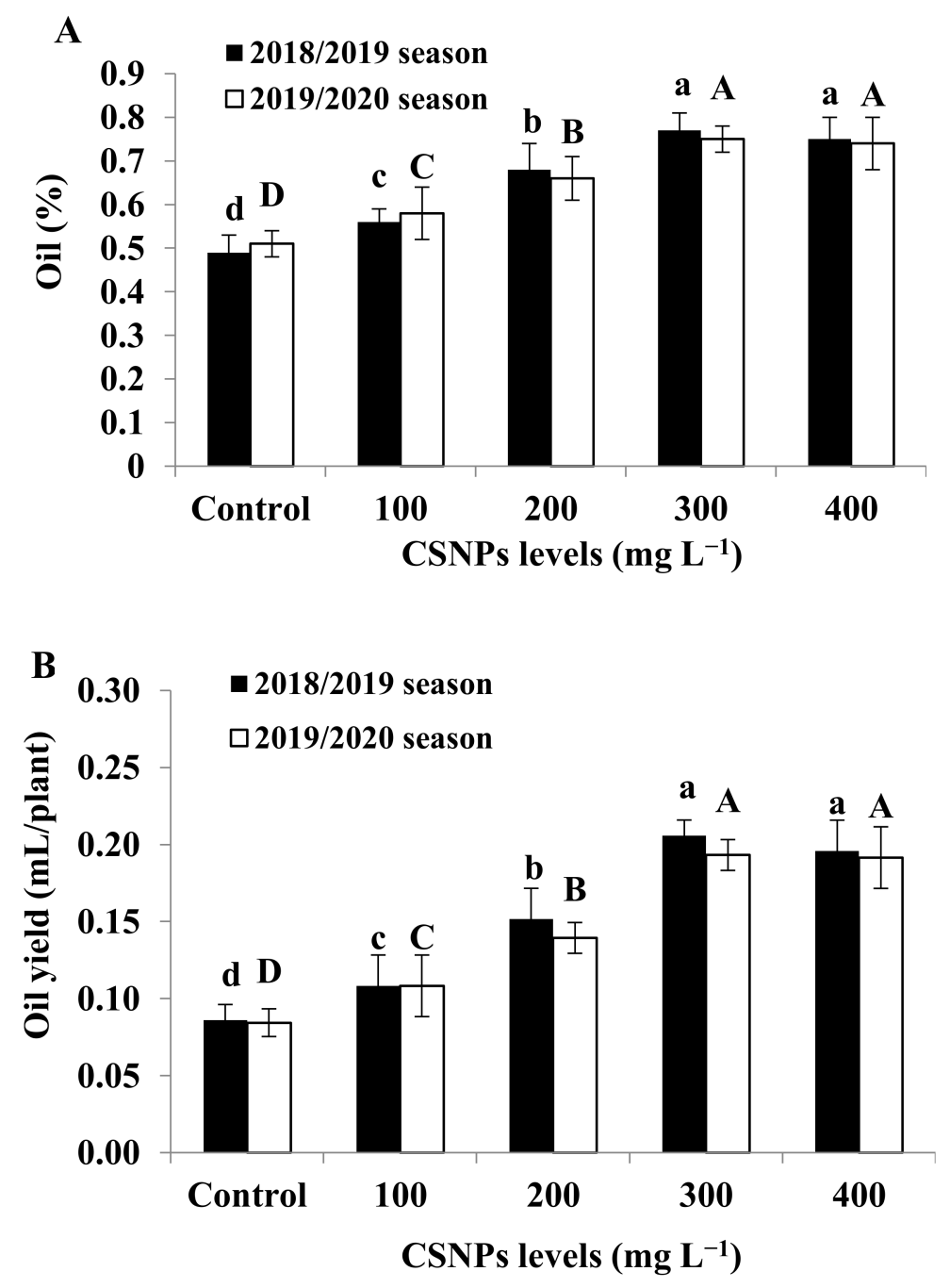

Figure 2. Impact of chitosan nanoparticles (CSNPs) on (A), essential oil percentage; (B), essential oil yield/plant of Matricaria chamomilla in the two experimental seasons. Data are means \pm SE $(n=3)$. In each season, letters represent statistical differences among the treatments at $5 \%$ probability.

\subsection{Photosynthetic Pigments}

Spraying chamomile plants with different levels of CSNPs significantly improved the photosynthetic pigments compared to the control in both experimental seasons (Table 2). The total chlorophyll and carotenoids contents were gradually increased with increasing the CSNPs concentrations and reached their maximum values by $300 \mathrm{mg} \mathrm{L}^{-1}$ level. Application of higher CSNPs dose did not cause any further significant improvement.

\subsection{Total Soluble Sugars (TSS)}

The impact of CSNPs application on TSS in chamomile herb during 2018/2019 and 2019/2020 seasons was presented in Table 2. The increase in CSNPs levels, the increase in TSS content in both seasons until $300 \mathrm{mg} \mathrm{L}^{-1}$ and a slight decrease was observed thereafter. The TSS was increased by 77.37 and $70.25 \%$ using $300 \mathrm{mg} \mathrm{L}^{-1}$ level relative to the control in both seasons, respectively. 
Table 2. Impact of chitosan nanoparticles (CSNPs) on chlorophyll, carotenoids and total soluble sugars (TSS) of Matricaria chamomilla in the two experimental seasons. Data are means $\pm \mathrm{SE}(n=3)$. In each column, least significant difference was calculated and letters represent the statistical differences among treatments at $p \leq 0.05$.

\begin{tabular}{|c|c|c|c|c|c|c|}
\hline \multirow[b]{2}{*}{$\begin{array}{l}\text { CSNPs } \\
\left(\mathrm{mg} \mathrm{L}^{-1}\right)\end{array}$} & \multicolumn{3}{|c|}{ 2018/2019 Season } & \multicolumn{3}{|c|}{ 2019/2020 Season } \\
\hline & $\begin{array}{c}\text { Total } \\
\text { Chlorophyll } \\
\left(\mathrm{mg} \mathrm{g}^{-1} \mathrm{FW}\right)\end{array}$ & $\begin{array}{l}\text { Carotenoids } \\
\left(\mathrm{mg} \mathrm{g}^{-1} \mathrm{FW}\right)\end{array}$ & $\begin{array}{c}\text { TSS } \\
\left(\mathrm{mg} \mathrm{g}^{-1} \mathrm{FW}\right)\end{array}$ & $\begin{array}{c}\text { Total } \\
\text { Chlorophyll } \\
\left(\mathrm{mg} \mathrm{g}^{-1} \mathrm{FW}\right)\end{array}$ & $\begin{array}{l}\text { Carotenoids } \\
\left(\mathrm{mg} \mathrm{g}^{-1} \mathrm{FW}\right)\end{array}$ & $\begin{array}{c}\text { TSS } \\
\left(\mathrm{mg} \mathrm{g}^{-1} \mathrm{FW}\right)\end{array}$ \\
\hline Control & $0.89 \pm 0.03 c$ & $0.31 \pm 0.02 \mathrm{~d}$ & $11.36 \pm 0.52 \mathrm{~d}$ & $0.91 \pm 0.02 \mathrm{~d}$ & $0.33 \pm 0.04 \mathrm{~d}$ & $12.27 \pm 0.38 \mathrm{~d}$ \\
\hline 100 & $0.93 \pm 0.04 c$ & $0.34 \pm 0.04 \mathrm{c}$ & $13.48 \pm 0.48 c$ & $0.96 \pm 0.04 \mathrm{c}$ & $0.36 \pm 0.02 c$ & $13.79 \pm 0.45 c$ \\
\hline 200 & $1.03 \pm 0.03 b$ & $0.39 \pm 0.03 b$ & $16.52 \pm 0.54 b$ & $1.14 \pm 0.03 b$ & $0.42 \pm 0.05 \mathrm{~b}$ & $16.12 \pm 0.40 \mathrm{~b}$ \\
\hline 300 & $1.25 \pm 0.05 \mathrm{a}$ & $0.43 \pm 0.02 \mathrm{a}$ & $20.15 \pm 0.46 a$ & $1.28 \pm 0.05 \mathrm{a}$ & $0.45 \pm 0.03 \mathrm{a}$ & $20.89 \pm 0.52 \mathrm{a}$ \\
\hline 400 & $1.23 \pm 0.06 \mathrm{a}$ & $0.42 \pm 0.04 \mathrm{a}$ & $19.89 \pm 0.49 \mathrm{a}$ & $1.29 \pm 0.04 \mathrm{a}$ & $0.44 \pm 0.02 \mathrm{a}$ & $20.09 \pm 0.43 a$ \\
\hline LSD 0.05 & 0.036 & 0.017 & 0.87 & 0.037 & 0.019 & 0.96 \\
\hline
\end{tabular}

\subsection{Total Phenolic Content}

Foliar application of CSNPs considerably increased the total phenolics in comparison to the untreated plants during the two seasons of study (Figure 3A). A progressive increase in phenolic content was observed with the increasing the CSNPs levels. The highest total phenolics were obtained by the treatment of $300 \mathrm{mg} \mathrm{L}^{-1}$. By applying this treatment, the total phenolics were 8.94 and $9.03 \mathrm{mg} \mathrm{GAE} \mathrm{g}^{-1} \mathrm{DW}$ compared to 2.66 and $2.75 \mathrm{mg} \mathrm{GAE} \mathrm{g}^{-1}$ DW recorded by the control during the two seasons, respectively.

\subsection{Antioxidant Activity (DPPH)}

The antioxidant activity of chamomile was significantly improved due to CSNPs application in the two experimental seasons compared to the control (Figure 3B). Increasing the CSNPs level resulted in a gradual decrease in $\mathrm{IC}_{50}$ values and the treatment of $400 \mathrm{mg} \mathrm{L}^{-1}$ CSNPs recorded the lowest values in both seasons but without significant difference with the $300 \mathrm{mg} \mathrm{L}^{-1}$ level. The antioxidant activity was 2.20 and 2.13-fold increase by applying CSNPs at $300 \mathrm{mg} \mathrm{L}^{-1}$ relative to the control during the two growing seasons, respectively.

\subsection{N, $P$ and K Contents}

Foliar application with CSNPs considerably enhanced the concentrations of N, P and $\mathrm{K}$ elements in chamomile herb in comparison to untreated plants during the two seasons (Table 3). The percentages of N, P and K were significantly and gradually increased by increasing the applied levels of CSNPs. However, there were no significant differences between 300 and $400 \mathrm{mg} \mathrm{L}^{-1}$ treatments in this respect.

\subsection{Principal Component Analysis (PCA)}

PCA showed that the first component had eigenvalue more than one and explained alone $98.7 \%$ of the variance in the data set according to the scree plot (Figure 4). The PCA biplot illustrated in Figure 5 shows the loading of different variables on the first two principal components (PC1 and PC2), which explained $99.8 \%$ of the variance. It appears that all the variables are strongly represented in the plot as clear from the long vectors. It is clear that all the variables positively correlated with PC1, except DPPH which showed a negative correlation. Meanwhile, PC2 exhibited positive correlation with DPPH, $\mathrm{K}$, RWC, branch number, chlorophyll, flower yield, TSS, oil yield and N, and negative correlation with the other variables. The biplot also provides invaluable information about the correlation between the variables. Positive correlations are clear among all variables, except DPPH, which negatively correlated with all the other variables. PC1 and PC2 successfully separated the effect of the applied CSNPs treatments. The effect of both treatments of CSNPs at 300 and $400 \mathrm{mg} \mathrm{L}^{-1}$ seemed to group together. Meanwhile the effect of the other treatments (the control, CSNPs at 100 and $200 \mathrm{mg} \mathrm{L}^{-1}$ ) varied strongly. 

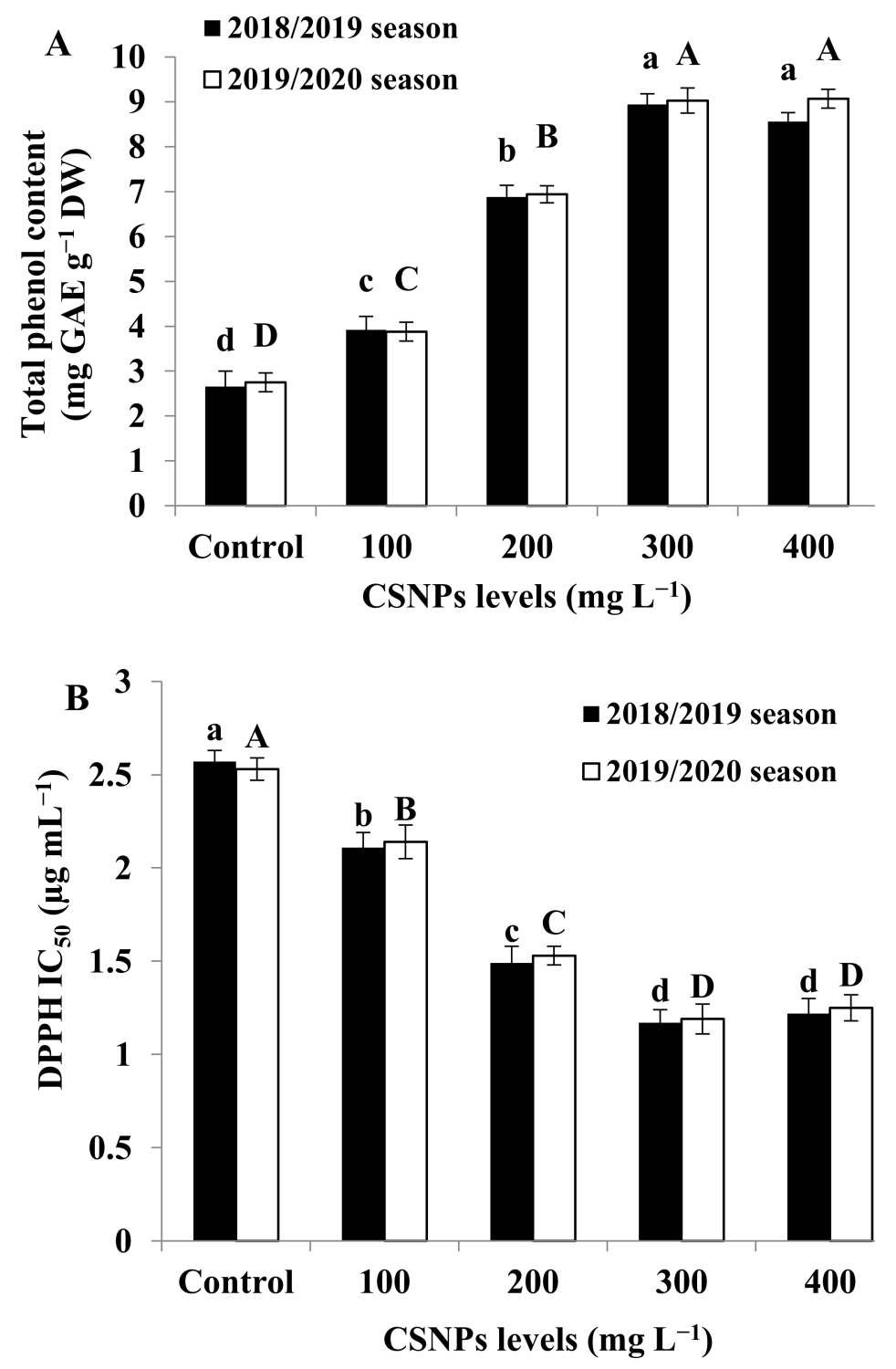

Figure 3. Impact of chitosan nanoparticles (CSNPs) on (A), total phenolic content and (B), antioxidant activity of Matricaria chamomilla in the two experimental seasons. Data are means $\pm \mathrm{SE}(n=3)$. In each season, letters represent statistical differences among the treatments at $5 \%$ probability.

Table 3. Impact of chitosan nanoparticles (CSNPs) on N, P and K percentages of Matricaria chamomilla in the two experimental seasons. Data are means \pm SE $(n=3)$. In each column, least significant difference was calculated and letters represent the statistical differences among treatments at $p \leq 0.05$.

\begin{tabular}{|c|c|c|c|c|c|c|}
\hline \multirow{2}{*}{$\begin{array}{l}\text { CSNPs } \\
\left(\mathrm{mg} \mathrm{L}^{-1}\right)\end{array}$} & \multicolumn{3}{|c|}{ 2018/2019 Season } & \multicolumn{3}{|c|}{ 2019/2020 Season } \\
\hline & N (\%) & $P(\%)$ & K (\%) & N (\%) & $P(\%)$ & K (\%) \\
\hline Control & $1.52 \pm 0.07 \mathrm{e}$ & $0.28 \pm 0.03 \mathrm{~d}$ & $1.62 \pm 0.05 \mathrm{~d}$ & $1.53 \pm 0.03 \mathrm{~d}$ & $0.30 \pm 0.06 c$ & $1.59 \pm 0.06 \mathrm{~d}$ \\
\hline 100 & $1.67 \pm 0.06 \mathrm{~d}$ & $0.32 \pm 0.02 c$ & $1.76 \pm 0.04 c$ & $1.69 \pm 0.05 c$ & $0.33 \pm 0.04 c$ & $1.74 \pm 0.05 c$ \\
\hline 200 & $1.89 \pm 0.05 c$ & $0.37 \pm 0.05 b$ & $1.92 \pm 0.05 b$ & $1.88 \pm 0.04 b$ & $0.38 \pm 0.05 b$ & $1.93 \pm 0.04 b$ \\
\hline 300 & $2.23 \pm 0.07 \mathrm{a}$ & $0.42 \pm 0.04 \mathrm{a}$ & $2.45 \pm 0.06 \mathrm{a}$ & $2.21 \pm 0.06 \mathrm{a}$ & $0.43 \pm 0.04 \mathrm{a}$ & $2.48 \pm 0.05 \mathrm{a}$ \\
\hline 400 & $2.11 \pm 0.08 \mathrm{~b}$ & $0.41 \pm 0.03 \mathrm{a}$ & $2.40 \pm 0.03 \mathrm{a}$ & $2.17 \pm 0.05 \mathrm{a}$ & $0.40 \pm 0.06 \mathrm{a}$ & $2.45 \pm 0.03 \mathrm{a}$ \\
\hline LSD 0.05 & 0.05 & 0.04 & 0.07 & 0.06 & 0.03 & 0.08 \\
\hline
\end{tabular}




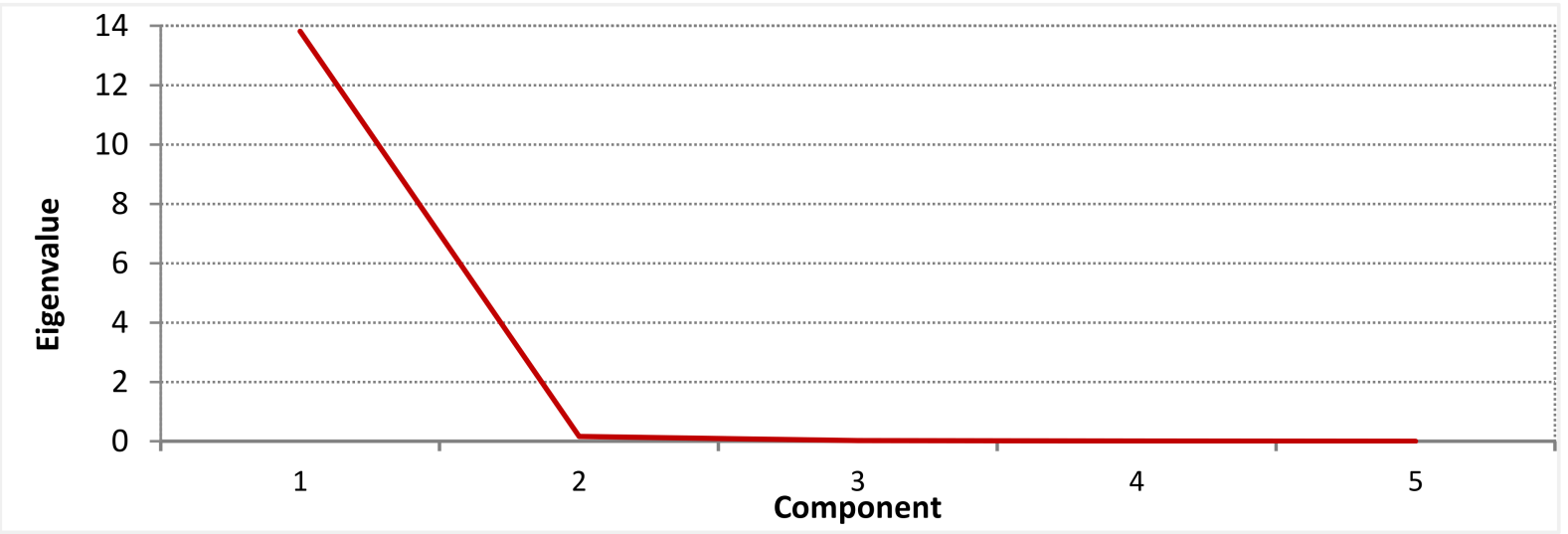

Figure 4. Scree plot of PCA components for chamomile plant parameters in response to CSNPs treatments.

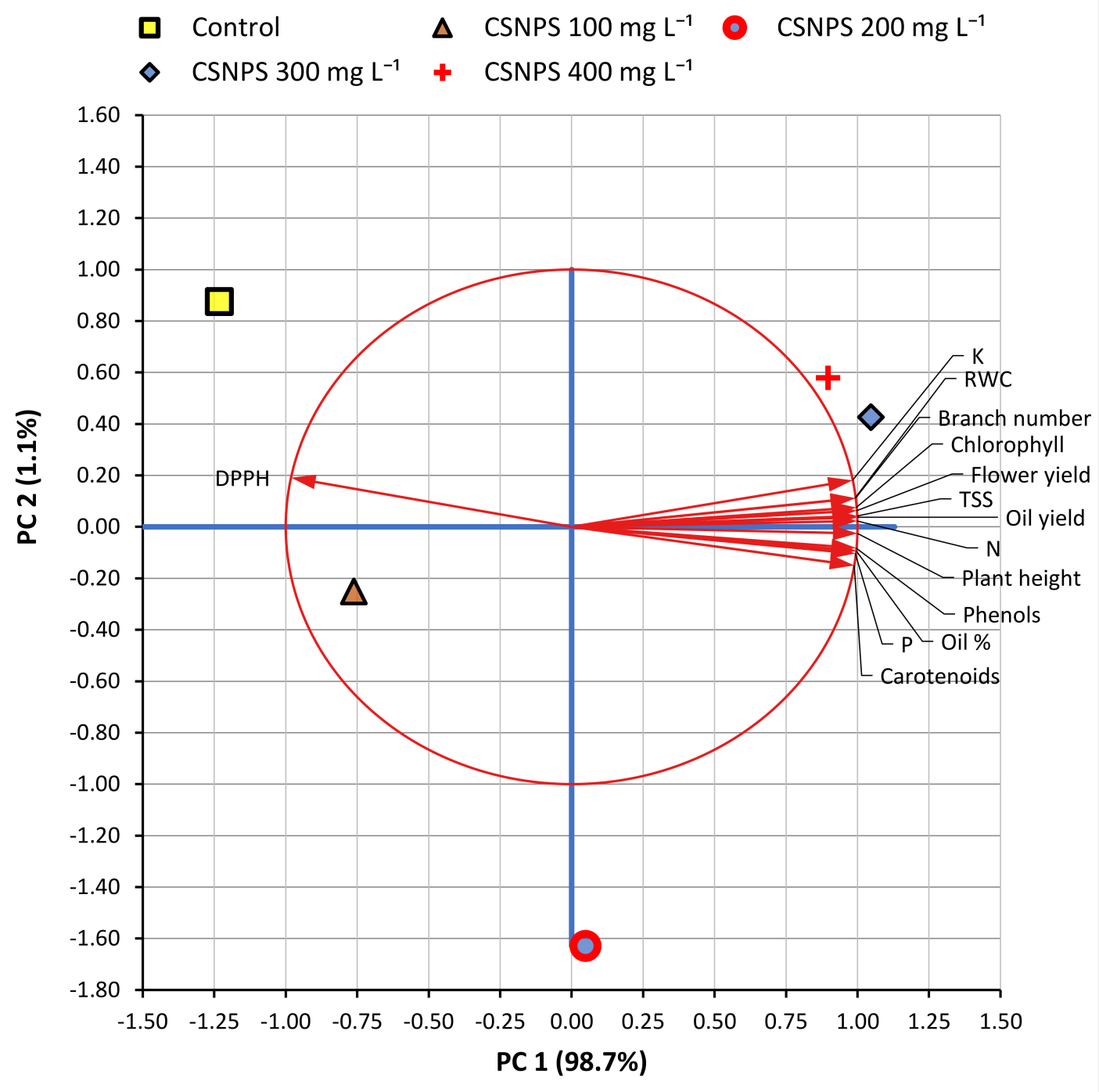

Figure 5. Biplot of the principal component analysis (PCA) for chamomile plant parameters in response to CSNPs treatments. The first two principal components (PC1 and PC2) explained 99.8\% of the total variation. The circle represents perfect (maximum) correlation $( \pm 1)$. The vectors (arrows) represent the variables, and the colored shapes represent sampling points under various treatments of CSNPs and the control. 


\section{Discussion}

The production of medicinal plants via non-traditional methods, particularly biostimulants, is very interesting topic. In this study, growth and productivity improvement of chamomile plants by foliar application of CSNPs was investigated. The growth characters of chamomile were significantly enhanced due to the CSNPs application. This improvement was accompanied by RWC and photosynthetic pigment level enhancements and a positive correlation was observed between them as shown by PCA (Figure 5). Chitosan induced the signaling pathways of several plant hormones such as auxins and gibberellins and regulated the carbon and nitrogen metabolisms [15] and therefore was involved in growth improvement [37]. Additionally, chitosan is able to increase the water uptake and the availability of essential nutrients (as our data indicated) by increasing the root growth and adjusting the cell osmotic pressure [38]. Additionally, chitosan treatment enhanced the activities of nitrogen metabolism key and increased the transportation of nitrogen in the functional leaves that enhanced growth and development [39]. Due to the small size and wide surface area of CSNPs it has been found to be more effective than bulk chitosan [24]. In accordance with current report, the impact of CSNPs on plant growth improvement has been observed in several medicinal species such as thyme [14] and sweet basil [13].

Maintaining the RWC and the photosynthetic pigments due to CSNPs in the current study may also explain its role as a plant growth enhancer. Enhancing the RWC in this study may be ascribed to the role of CSNPs in inducing the stomatal closure through the activation of ABA signaling pathway [40]. Increasing the RWC by CSNPs has been previously reported [41]. It has been found that chitosan application could enhance the chlorophyll content [42] which in accordance with current results. Further, improving the RWC and photosynthetic pigments in this study indicate that CSNPs can enhance the photosynthesis performance [43] and the net photosynthesis rate [44] and therefore increasing the TSS was observed in current study. In some species, osmotic adjustment to maintain leaf turgor pressure requires an increase in solutes mainly soluble sugars. In agreement with our results, increasing the TSS due to chitosan application has been reported [13]. As a consequence of the previous roles of CSNPs, the flower yield was increased accordingly which support the previous reports in thyme [14] and sweet basil [13].

Interestingly, CSNPs application improved the essential oil content in chamomile flowers. Positive correlation between growth, photosynthetic pigments, nutrient content and TSS in one side and essential oil content in the other side was clearly observed (Figure 5). Therefore, these results may be due to the role of CSNPs in increasing the water content, nutrient uptake, photosynthetic pigments and TSS which resulted in higher growth rate which may motivate the efficiency of the translocation and assimilation and translocation of photosynthetic products and other metabolites to the reproductive parts [18,22]. In agreement with our results, chitosan application increased the essential oil content in thyme [14] and Origanium vulgare [45]. The total phenolics were enhanced due to the application of CSNPs in the current study. It has been found that chitosan treatment effectively improves the biosynthesis of phenolic compounds [46]. In agreement with our results, the total phenolics and terpenic compound levels were improved due to chitosan application in sweet basil [47].

It is widely known that DPPH is a free radical that used as a tool to estimate free radical scavenging activity [48]. Interestingly, the foliar application of CSNPs improved the antioxidant activity of chamomile since all CSNPs levels recorded lower $\mathrm{IC}_{50}$ values relative to untreated plants. Therefore, CSNPs shows a strong ability to act as a scavenger of reactive oxygen species (ROS). It is well known that antioxidant activity is influenced by enzymatic and non-enzymatic antioxidants [8]. Thus, the improved antioxidant activity may be explained by the role of CSNPs treatment in increasing the total phenolics in the current report (Figure 3). Because the flower is a very sensitive organ [49], stimulating the antioxidant system is required to prevent lipid peroxidation and protect the cell membrane functions $[18,19,50,51]$. The impact of chitosan in improving the antioxidant system in plant tissues has been documented [52]. 


\section{Conclusions}

Foliar application of CSNPs enhanced the growth and productivity of chamomile plants. It also improved the photosynthetic pigment levels, TSS and N, P and K percentages. Interestingly, CSNPs increased the essential oil content, total phenolics and the antioxidant activity. Taking into consideration the eco-friendly properties of CSNPs, they could be an effective treatment and alternative strategy for increasing the productivity, and quality and decreasing the production cost of chamomile and perhaps other medicinal species. The current results suggest that CSNPs can be used as a natural and valuable biostimulant in the production of medicinal plants without environmental contamination.

Author Contributions: Conceptualization, F.A.S.H. and E.F.A.; methodology, R.M.; software, S.H. and F.A.S.H.; validation, E.F.A., F.A.S.H. and R.M.; formal analysis, E.F.A.; investigation, R.M.; resources, S.H. and F.A.S.H.; data curation, E.F.A.; writing - original draft preparation, F.A.S.H.; writing-review and editing, F.A.S.H. and S.H.; visualization, E.F.A.; supervision, F.A.S.H.; project administration, E.F.A.; funding acquisition, S.H. All authors have read and agreed to the published version of the manuscript.

Funding: This research was funded by Taif University, grant number (TURSP-2020/142).

Institutional Review Board Statement: Not applicable.

Informed Consent Statement: Not applicable.

Data Availability Statement: The data sets supporting the results of this research are included within the article.

Acknowledgments: The authors acknowledge Taif University Researchers Supporting Project number (TURSP-2020/142), Taif University, Taif, Saudi Arabia.

Conflicts of Interest: The authors declare no conflict of interest.

\section{References}

1. Wichtl, M. Herbal Drugs and Phytopharmaceuticals: A Handbook of Practice on a Scientific Basis, 3rd ed.; CRC Press: Stuttgart, Germany, 2004.

2. Bączek, K.B.; Wiśniewska, M.; Przybył, J.L.; Kosakowska, O.; Węglarz, Z. Arbuscular mycorrhizal fungi in chamomile (Matricaria recutita L.) organic Cultivation. Ind. Crop. Prod. 2019, 140, 111562. [CrossRef]

3. Mazrou, R. Salt stress alleviation of chamomile plant by Mycorrhizal fungi and salicylic acid. Int. J. Curr. Microbiol. App. Sci. 2017, 6, 5099-5111.

4. Avallone, R.; Zanoli, P.; Puia, G.; Kleinschnitz, M.; Schreier, P.; Baraldi, M. Pharmacological profile of apigenin, a flavonoid isolated from Matricaria chamomilla. Biochem. Pharmacol. 2000, 59, 1387-1394. [CrossRef]

5. Hassan, F; Ali, E.F. Protective effects of 1-methylcyclopropene and salicylic acid on senescence regulation of gladiolus cut spikes. Sci. Hortic. 2014, 179, 146-152. [CrossRef]

6. Pandey, V.; Patra, D.D. Crop productivity, aroma profile and antioxidant activity in Pelargonium graveolens L'Hér. under integrated supply of various organic and chemical fertilizers. Ind. Crop. Prod. 2015, 67, 257-263. [CrossRef]

7. Kahil, A.A.; Hassan, F.A.S.; Ali, E.F. Influence of bio-fertilizers on growth, yield and anthocyanin content of Hibiscus sabdariffa L. plant under Taif region conditions. Annu. Res. Rev. Biol. 2017, 17, 1-15. [CrossRef]

8. Ali, E.F.; Hassan, F.A.S.; Elgimabi, M. Improving the growth, yield and volatile oil content of Pelargonium graveolens L. Herit by foliar application with moringa leaf extract through motivating physiological and biochemical paramètres. S. Afr. J. Bot. 2018, 119, 383-389. [CrossRef]

9. Hassan, F.A.S.; Fetouh, M.I. Does moringa leaf extract have preservative effect improving the longevity and postharvest quality of gladiolus cut spikes? Sci. Hortic. 2019, 250, 287-293. [CrossRef]

10. Hassan, F.A.S.; Mazrou, R.; Gaber, A.; Hassan, M. Moringa extract preserved the vase life of cut roses through maintaining water relations and enhancing antioxidant machinery. Postharvest Biol. Technol. 2020, 164, 111156. [CrossRef]

11. Ali, E.F.; Hassan, F. Bio-production of Nigella sativa L. seeds and oil in Taif area. Int. J. Curr. Microbiol. App. Sci. 2014, 3, 315-328.

12. Pichyangkura, R.; Chadchawan, S. Biostimulant activity of chitosan in horticulture. Sci. Hortic. 2015, 196, 49-65. [CrossRef]

13. Pirbalouti, G.A.; Malekpoor, F.; Salimi, A.; Golparvar, A. Exogenous application of chitosan on biochemical and physiological characteristics, phenolic content and antioxidant activity of two species of basil (Ocimum ciliatum and Ocimum basilicum) under reduced irrigation. Sci. Hortic. 2017, 217, 114-122. [CrossRef]

14. Bistgani, E.; Zohreh Siadat, S.A.; Bakhshandeh, A.; Ghasemi Pirbalouti, A.; Hashemi, M. Interactive effects of drought stress and chitosan application on physiological characteristics and essential oil yield of Thymus daenensis Celak. Crop J. 2017, 5, 407-415. [CrossRef] 
15. Safikhan, S.; Khoshbakht, K.; Chaichi, M.R.; Amini, A.; Motesharezadeh, B. Role of chitosan on the growth, physiological parameters and enzymatic activity of milk thistle (Silybum marianum (L.) Gaertn.) in a pot experiment. J. Appl. Res. Med. Arom. Plants 2018, 10, 49-58. [CrossRef]

16. Lei, C.; Ma, D.; Pu, G.; Qiu, X.; Du, Z.; Wang, H.; Li, G.; Ye, H.; Liu, B. Foliar application of chitosan activates artemisinin biosynthesis in Artemisia annua L. Ind. Crop. Prod. 2011, 33, 176-182. [CrossRef]

17. Hidangmayum, A.; Dwivedi, P.; Katiyar, D.; Hemantaranjan, A. Application of chitosan on plant responses with special reference to abiotic stress. Physiol. Mol. Biol. Plants Int. J. Funct. Plant Biol. 2019, 25, 313-326. [CrossRef] [PubMed]

18. Hassan, F.A.S.; Ali, E.; Gaber, A.; Fetouh, M.; Mazrou, R. Chitosan nanoparticles effectively combat salinity stress by enhancing antioxidant activity and alkaloid biosynthesis in Catharanthus roseus (L.) G. Don. Plant Physiol. Biochem. 2021, 162, 291-300. [CrossRef]

19. Hassan, F.A.S.; Ali, E.F.; El-Deeb, B. Improvement of postharvest quality of cut rose cv. 'First Red' by biologically synthesized silver nanoparticles. Sci. Hortic. 2014, 179, 340-348. [CrossRef]

20. Song, H.; Yuan, W.; Jin, P.; Wang, W.; Wang, X.; Yang, L.; Zhang, Y. Effects of chitosan/nano-silica on postharvest quality and antioxidant capacity of loquat fruit during cold storage. Postharvest Biol. Technol. 2016, 119, 41-48. [CrossRef]

21. Tokatl, K.; Demirdöven, A. Effects of chitosan edible film coatings on the physicochemical and microbiological qualities of sweet cherry (Prunus avium L.). Sci. Hortic. 2020, 259, 108656. [CrossRef]

22. Ali, E.F.; El-Shehawi, A.M.; Ibrahim, O.H.M.; Abdul-Hafeez, E.Y.; Moussa, M.M.; Hassan, F.A.S. A vital role of chitosan nanoparticles in improvisation the drought stress tolerance in Catharanthus roseus (L.) through biochemical and gene expression modulation. Plant Physiol. Biochem. 2021, 161, 166-175. [CrossRef] [PubMed]

23. Hassan, F.A.S.; Ali, E.F.; Mostafa, N.Y.; Mazrou, R. Shelf-life extension of sweet basil leaves by edible coating with thyme volatile oil encapsulated chitosan nanoparticles. Int. J. Biol. Macro. 2021, 177, 517-525. [CrossRef]

24. Divya, K.; Jisha, M.S. Chitosan nanoparticles preparation and applications. Environ. Chem. Lett. 2018, 16, 101-112. [CrossRef]

25. Fan, W.; Yan, W.; Xu, Z. Formation mechanism of monodisperse, low molecular weight chitosan nanoparticles by ionic gelation technique. Colloids Surf. B Biointerfaces 2012, 90, 21-27.

26. Snedecor, G.W.; Cochran, W.G. Statistical Methods, 7th ed.; Iowa State University Press: Ames, IA, USA, 1980.

27. Weatherley, P.E. Studies in the water relations of the cotton plant. 1. The field measurements of water deficit in leaves. New Phytol. 1950, 49, 8. [CrossRef]

28. British Pharmacopea. Determination of Volatile Oil in Drugs; Pharmaceutical Press: London, UK, 1963.

29. Lichtenthaler, H.K.; Wellburn, A.R. Determinations of total carotenoids and chlorophylls a and b of leaf extracts in different solvents. Biochem. Soc. Trans. 1983, 11, 591-592. [CrossRef]

30. Shi, H.; Qian, Y.; Tan, D.-X.; Reiter, R.J.; He, C. Melatonin induces the transcripts of CBF/DREB1 and their involvement in both abiotic and biotic stresses in Arabidopsis. J. Pineal. Res. 2015, 59, 334-342. [CrossRef]

31. McDonald, S.; Prenzler, P.D.; Antolovich, M.; Robards, K. Phenolic content and antioxidant activity of olive extracts. Food Chem. 2001, 73, 73-84. [CrossRef]

32. Brand-Williams, W.; Cuvelier, M.E.; Berset, C. Use of a free radical method to evaluate antioxidant activity. Lebensm. Wiss. Technol. 1995, 28, 25-30. [CrossRef]

33. A.O.A.C. Official Method of Analysis, 16th ed.; Association of Official Analytical Chemists International: Washington, DC, USA, 1995. Available online: https://www.worldcat.org/title/official-methods-of-analysis-of-aoac-international/oclc/421897987 (accessed on 13 August 2018).

34. Nelson, D.W.; Sommers, L.E. Determination of total nitrogen in plant material. Agron. J. 1973, 65, 109-112. [CrossRef]

35. Jackson, M.L. Soil Chemical Analysis; Prentice-Hall of India: New Delhi, India, 1967; pp. 144-197.

36. Page, A.L.; Miller, R.H.; Keeney, D.R. Methods of Soil Analysis. Part II. Chemical and Microbiological Properties, 2nd ed.; American Society of Agronomy: Madison, WI, USA, 1985.

37. Zhang, X.; Li, K.; Xing, R.; Liu, S.; Li, P. Metabolite Profiling of Wheat Seedlings Induced by Chitosan: Revelation of the Enhanced Carbon and Nitrogen Metabolism. Front. Plant Sci. 2017, 8. [CrossRef] [PubMed]

38. Guan, Y.J.; Hu, J.; Wang, X.; Shao, C. Seed priming with chitosan improves maize germination and seedling growth in relation to physiological changes under low temperature stress. J. Zhejiang Univ. Sci. 2009, 10, 427-433. [CrossRef] [PubMed]

39. Gornik, K.; Grzesik, M.; Duda, B.R. The effect of chitosan on rooting of grave vine cuttings and on subsequent plant growth under drought and temperature stress. J. Fruit Ornam. Plant Res. 2008, 16, 333-343.

40. Veroneze-Júnior, V.; Martins, M.; Mc Leod, L.; Souza, K.R.D.; Santos-Filho, P.R.; Magalhães, P.C.; Carvalho, D.T.; Santos, M.H.; Souza, T.C. Leaf application of chitosan and physiological evaluation of maize hybrids contrasting for drought tolerance under water restriction. Braz. J. Biol. 2020, 80, 631-640. [CrossRef]

41. Zeng, D.; Luo, X. Physiological Effects of Chitosan Coating on Wheat Growth and Activities of Protective Enzyme with Drought Tolerance. Open J. Soil Sci. 2012, 2, 282-288. [CrossRef]

42. Sharma, G.; Kumar, A.; Devi, K.A.; Prajapati, D.; Bhagat, D.; Pal, A.; Raliya, R.; Biswas, P.; Saharan, V. Chitosan nanofertilizer to foster source activity in maize. Int. J. Biol. Macro. 2020, 145, 226-234. [CrossRef]

43. Katiyar, D.; Hemantaranjan, A.; Singh, B. Chitosan as a promising natural compound to enhance potential physiological responses in plant: A review. Indian J. Plant Physiol. 2015, 20, 1-9. [CrossRef] 
44. Van, S.N.; Minh, H.D.; Anh, D.N. Study on chitosan nanoparticles on biophysical characteristics and growth of Robusta coffee in green house. Biocatal. Agric. Biotechnol. 2013, 2, 289-294.

45. Yin, H.; Fretté, X.C.; Chrestensen, L.P.; Grevsen, K. Chitosan oligosaccharides promote the content of polyphenols in Greek oregano (Oreganum vulgare ssp. hirtum). J. Agric. Food Chem. 2011, 60, 136-143. [CrossRef] [PubMed]

46. Cai, Z.; Kastell, A.; Mewis, I.; Knorr, D.; Smetanska, I. Polysaccharide elicitorsenhance anthocyanin and phenolic acid accumulation in cell suspension cultures of Vitis vinifera. Plant Cell Tissue Organ Cult. 2012, 108, 401-409. [CrossRef]

47. Kim, H.J.; Chen, F.; Wang, X.; Rajapakse, N.C. Effect of chitosan on the biological properties of sweet basil (Ocimum basilicum L.). J. Agric. Food Chem. 2005, 53, 3696-3701. [CrossRef] [PubMed]

48. Hu, Q.; Xu, J.; Chen, S.; Yang, F. Antioxidant activity of extracts of black sesame seed (Sesamum indicum L.) by supercritical carbon dioxide extraction. J. Agric. Food Chem. 2004, 52, 943-947. [CrossRef] [PubMed]

49. Hassan, F.; Schmidt, G. Post-harvest characteristics of cut carnations as the result of chemical treatments. Acta Agron. Hung. 2004, 52, 125-132. [CrossRef]

50. Hassan, F.; Ali, E.F. Effects of salt stress on growth, antioxidant enzyme activity and some other physiological parameters in jojoba (Simmondsia chinensis (Link) Schneider) plant. Aust. J. Crop Sci. 2014, 8, 1615-1624.

51. Hassan, F.A.S.; Ali, E.F.; Alamer, K.H. Exogenous application of polyamines alleviates water stress-induced oxidative stress of Rosa damascena Miller var. trigintipetala Dieck. S. Afr. J. Bot. 2018, 116, 96-102. [CrossRef]

52. Li, Z.; Zhang, Y.; Zhang, X.; Merewitz, E.; Peng, Y.; Ma, X.; Huang, L.; Yan, Y. Metabolic Pathways Regulated by Chitosan Contributing to Drought Resistance in White Clover. J. Proteome Res. 2017, 16, 3039-3052. [CrossRef] 